\title{
Reconstruction of temperature experienced by Pacific bluefin tuna Thunnus orientalis larvae using SIMS and microvolume CF-IRMS otolith oxygen isotope analyses
}

\author{
Yulina Hane ${ }^{1,2, *}$, Shingo Kimura ${ }^{1,2}$, Yusuke Yokoyama ${ }^{2,3,4}$, Yosuke Miyairi², \\ Takayuki Ushikubo ${ }^{5}$, Toyoho Ishimura ${ }^{6,7}$, Nobuhiro Ogawa ${ }^{2}$, Tomoya Aono ${ }^{2,6}$, \\ Kozue Nishida ${ }^{6,8}$
}

\footnotetext{
${ }^{1}$ Graduate School of Frontier Sciences, The University of Tokyo, Kashiwanoha, Kashiwa, Chiba 277-8564, Japan

${ }^{2}$ Atmosphere and Ocean Research Institute, The University of Tokyo, Kashiwanoha, Kashiwa, Chiba 277-8564, Japan

${ }^{3}$ Department of Earth and Planetary Science, Graduate School of Science, The University of Tokyo, Hongo, Tokyo 113-0033, Japan

${ }^{4}$ Organization for Programs on Environmental Sciences, Graduate School of Arts and Sciences, The University of Tokyo, Komaba, Tokyo 153-8902, Japan

${ }^{5}$ Kochi Institute for Core Sample Research, Japan Agency for Marine-Earth Science and Technology (JAMSTEC), Nankoku, Kochi 783-8502, Japan

${ }^{6}$ National Institute of Technology, Ibaraki College, Hitachinaka, Ibaraki 312-8508, Japan

${ }^{7}$ Graduate School of Human and Environmental Studies, Kyoto University, Yoshida-nihonmatsu-cho, Sakyo-ku, Kyoto 606-8501, Japan

${ }^{8}$ Graduate School of Life and Environmental Sciences, University of Tsukuba, 1-1-1 Tennodai, Tsukuba 305-8572, Japan
}

\begin{abstract}
This study aimed to reconstruct temperatures experienced during the larval period by adult Pacific bluefin tuna Thunnus orientalis using high-resolution otolith stable oxygen isotope $\left(\delta^{18} \mathrm{O}\right)$ analysis. A novel otolith sample preparation protocol for secondary ion mass spectrometry (SIMS) analysis developed in this study reduced the background noise of SIMS measurements, enabling analyses of $>10$ times higher resolution around the otolith core compared to previous studies using conventional isotope ratio mass spectrometry (IRMS). The values obtained from SIMS were compared to those obtained by microvolume $\delta^{18} \mathrm{O}_{\text {otolith }}$ analysis using micromilling and conventional continuous-flow IRMS (CF-IRMS). There was a systematic offset (average $0.41 \%$ with SIMS resulting in lower values) most likely caused by matrix effects on SIMS $\delta^{18} \mathrm{O}_{\text {otolith }}$ values that can be calibrated using a strong linear relationship between SIMS and CFIRMS measurements $\left(\mathrm{r}^{2}=0.78, \mathrm{p}<0.001\right)$. The core-to-edge $\delta^{18} \mathrm{O}_{\text {otolith }}$ of 5 Pacific bluefin tuna revealed fine-scale seasonal variations in water temperature agreeing with known migration patterns. In addition, the ambient water temperature experienced during larval stages (about 10$20 \mathrm{~d}$ post hatch) estimated from otolith core $\delta^{18} \mathrm{O}$ ranged from 26.7 to $30.7^{\circ} \mathrm{C}$, overlapping with temperatures associated with the occurrence of larval Pacific bluefin tuna. Combining SIMS and microvolume CF-IRMS $\delta^{18} \mathrm{O}$ otolith analyses offers a microscale examination of fish ecology that is not possible with conventional IRMS techniques. This novel method is particularly useful for understanding the early life history of fish that may be affected by climate change and reconstructing a well-resolved migration history for fish species that have small otoliths and/or narrow growth increments.
\end{abstract}

KEY WORDS: Temperature reconstruction - Otolith · Oxygen isotope analysis · Secondary ion mass spectrometry $\cdot$ SIMS $\cdot$ continuous-flow isotope ratio mass spectrometry $\cdot$ CF-IRMS $\cdot$ Pacific bluefin tuna $\cdot$ Sample preparation protocol

*Corresponding author: yulinahane@s.nenv.k.u-tokyo.ac.jp
(C) The authors 2020. Open Access under Creative Commons by Attribution Licence. Use, distribution and reproduction are unrestricted. Authors and original publication must be credited. 


\section{INTRODUCTION}

Ocean warming has significant impacts on marine species and ecosystems, including high mortality, distribution shifts, and loss of spawning and nursery habitats (Perry et al. 2005, Kimura et al. 2010, Muhling et al. 2011, 2015). Species that spawn seasonally in relatively limited areas are particularly vulnerable to increasing water temperature, as their optimum range in spawning temperatures tends to be restricted. Pacific bluefin tuna Thunnus orientalis (PBT) is a highly migratory species that spawns in waters near the Nansei Islands in the western North Pacific from May to June and in the Sea of Japan from July to August (Yonemori 1989, Ohshimo et al. 2017). Adult fish in the western North Pacific spawn at temperatures between 26 and $29^{\circ} \mathrm{C}$, whereas those in the Sea of Japan initiate spawning at temperatures greater than $20^{\circ} \mathrm{C}$ (Chen et al. 2006, Tanaka 2011, Suzuki et al. 2014, Okochi et al. 2016). In the laboratory, the growth rate and survival of PBT larvae significantly decrease when temperatures exceed $29^{\circ} \mathrm{C}$ (Kimura et al. 2007). In fact, projected temperature in the current spawning sites is expected to increase by more than $3^{\circ} \mathrm{C}$ by 2100 under the most extreme Intergovernmental Panel on Climate Change (IPCC) climatewarming scenario (IPCC 2007) and become unsuitable for PBT to spawn (Kimura et al. 2010). As PBT larvae are particularly vulnerable to thermal stress, warming sea temperatures are likely to have significant impacts on their early growth and survival. However, the effects of ongoing climate change on the early life stages of PBT are poorly understood due to a lack of empirical evidence and methods to study such effects.

Oxygen isotope ratios $\left(\delta^{18} \mathrm{O}\right)$ in otoliths, biogenic calcium carbonate (aragonite) found in the inner ear of teleost fish (ray-finned bony fish), has been widely used as a natural tag to reconstruct water temperatures and salinity conditions experienced by fish (Thorrold et al. 1997, Campana 1999, Jones \& Campana 2009). Such reconstructions of past environment are possible because otoliths generally develop at or close to the isotope equilibrium with ambient water, and many studies have demonstrated the temperature dependency of otolith $\delta^{18} \mathrm{O}$ for various fish species under laboratory conditions (Kalish 1991, Thorrold et al. 1997, Høie et al. 2004, Kitagawa et al. 2013). Existing methods of temperature reconstruction for fish mostly rely on $\delta^{18} \mathrm{O}_{\text {otolith }}$ measurements by conventional isotope ratio mass spectrometry (IRMS), which often involves a milling process to obtain a relatively large amount of otolith powder for analysis (usually more than a few tens of micrograms with a minimum weight requirement of $15 \mu \mathrm{g}$ ). Ambient water temperatures have previously been reconstructed using IRMS for sockeye salmon Oncorhynchus nerka (Zazzo et al. 2006), alewife Alosa pseudoharengus (Dufour et al. 2008), Atlantic cod Gadus morhua (Jones \& Campana 2009, von Leesen et al. 2020), turbot Scophthalmus maximus (Imsland et al. 2014), and chub mackerel Scomber japonicus (Higuchi et al. 2019), most of which have a monthly to annual resolution depending on the otolith size. The limited temporal resolution due to the sample mass requirement of the IRMS is inevitable and makes it particularly difficult when analyzing the otolith core and edge.

Recent developments in secondary ion mass spectrometry (SIMS) $\delta^{18} \mathrm{O}$ analysis of otoliths have enabled a high-resolution reconstruction of migration and life history characteristics of marine species (Hanson et al. 2010, Matta et al. 2013, Shiao et al. 2014, Helser et al. 2018a, Shirai et al. 2018, Willmes et al. 2019). Unlike conventional IRMS, SIMS is capable of determining isotopic composition within a spatial resolution of 5 to $15 \mu \mathrm{m}$, which allows subannual, seasonal, and even weekly or much shorter timescale analyses with high accuracy and precision (Kita et al. 2009, Valley \& Kita 2009). While a recent study (Sakamoto et al. 2019) reconstructed migration histories of an individual Japanese sardine Sardinops melanostictus with 10 to $30 \mathrm{~d}$ resolution (20 to $30 \mathrm{~d}$ around the core regions and 10 to $15 \mathrm{~d}$ toward the edge) using microvolume isotope analysis measured by continuous-flow IRMS (CF-IRMS), SIMS provides even finer temporal resolution, particularly for the otolith core and edge. High-resolution reconstruction of experienced temperatures using SIMS $\delta^{18} \mathrm{O}_{\text {otolith }}$ is an effective method for investigating the early life history of fish in response to increasing water temperature associated with climate change.

In this study, we developed a method to reconstruct ambient water temperatures experienced during the larval period of an individual fish using SIMS $\delta^{18} \mathrm{O}_{\text {otolith }}$ analysis. $\delta^{18} \mathrm{O}_{\text {otolith }}$ values of 5 adult PBT otolith samples were measured from the otolith core to edge by SIMS, and the measured SIMS $\delta^{18} \mathrm{O}_{\text {otolith }}$ values were compared to those measured by $\mathrm{CF}$ IRMS. Water temperatures were then estimated using a temperature-dependent oxygen isotope fractionation equation for PBT larvae that had already been established in a previous study (Kitagawa et al. 2013). The temperature reconstruction technique presented here allows high-resolution investigation of the early life history of fish and provides a more 
thorough understanding of the characteristics of survivors and the thermal environment that may constrain their early growth and survival.

\section{MATERIALS AND METHODS}

\subsection{Sample collection and sample preparation protocol}

Sagittal otoliths, the largest of 3 pairs of otoliths, were collected from the heads of PBT caught in waters south of Japan in the Pacific by local longline fishing vessels and small ships from 2017 to 2018 (Fig. 1, Table 1). Catch location, date of catch, and biological information of PBT samples are shown in Table 1. Otoliths were cleaned and rinsed with double deionized water (Milli-Q water) to remove any remaining muscle tissues, air-dried in a clean environment, and stored in microtubes for later analysis. Five adult fish samples were randomly selected and 1 of the paired otoliths from each individual was used for SIMS $\delta^{18} \mathrm{O}$ analysis. For CF-IRMS $\delta^{18} \mathrm{O}$ analysis, the 3 otolith sections that had been analyzed by SIMS were used.

Since SIMS is a surface analytical method, any irregularities of the sample surface, such as the existence of cracks, sample relief, and inclination of the surface, can cause degraded accuracy and precision of SIMS measurements (Kita et al. 2009, Valley \& Kita 2009). It is also difficult to prepare samples with otolith cores and standard materials exposed on the same flat mirror-finished surface because otolith cores are usually very small $(<5 \mu \mathrm{m})$. Thus, we first developed a sample preparation protocol (Fig. 2) that minimizes the effect of sample surface irregularities with an appropriate polishing procedure for calcium carbonates. This protocol is appropriate for preparing

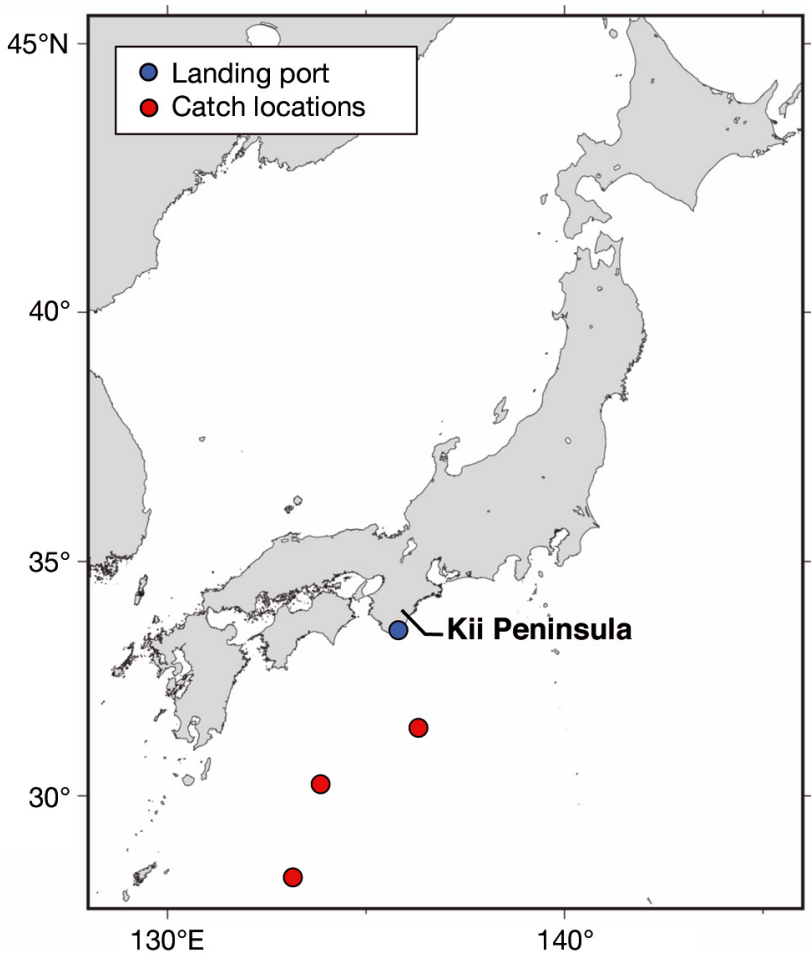

Fig. 1. Catch locations of Pacific bluefin tuna Thunnus orientalis (red circles). Two samples (T118R and T131R) were caught in nearshore waters off Kii Peninsula by a small local

boat and thus the locations are not shown on the map

a thin otolith section with a transverse (or sagittal) cross-sectional plane. First, an otolith was mounted on a microscope slide with thermoplastic cement perpendicular to its longest axis, with the sulcus side facing down. The otolith core was then observed under an inverted microscope (IX-71, Olympus) equipped with a high-resolution color CMOS camera (DP-74, Olympus). Next, straight lines were drawn on the glass slide at 270 to $300 \mu \mathrm{m}$ on each side of the otolith core using waterproof ink and a comic pen (Zebra

Table 1. Biological information, sampling data, and $\delta^{18} \mathrm{O}$ analyses of Pacific bluefin tuna Thunnus orientalis otoliths used in the present study. Fork length was calculated with a weight-length relationship established by Kai (2007). Two life-history transect lines were analyzed for T64R by SIMS. *Numbers in parentheses indicate the number of supplementary samples (removed otolith powders that were milled before milling the target milling areas to avoid cross-contamination) analyzed by CF-IRMS

\begin{tabular}{|lcrrrrr|}
\hline Sample ID & Catch location & Date of catch & $\begin{array}{c}\text { Weight } \\
(\mathrm{kg})\end{array}$ & $\begin{array}{c}\text { Estimated } \\
\text { fork length } \\
(\mathrm{cm})\end{array}$ & $\begin{array}{c}\text { Number } \\
\text { of SIMS } \\
\text { spots }\end{array}$ & $\begin{array}{c}\text { Number of } \\
\text { CF-IRMS } \\
\text { measurements }\end{array}$ \\
\hline T64R & $30.0^{\circ} \mathrm{N}, 134.0^{\circ} \mathrm{E}$ & 26 April 2017 & 146.0 & 191.1 & $78(35$ and 43$)$ & $5(2)^{*}$ \\
T75R & $30.0-32.0^{\circ} \mathrm{N}, 136.0^{\circ} \mathrm{E}$ & 30 April 2017 & 52.2 & 136.2 & 42 & - \\
T104L & $27.0-28.0^{\circ} \mathrm{N}, 132.0-134.0^{\circ} \mathrm{E}$ & 18 May 2017 & 99.2 & 168.3 & 53 & $8(3)^{*}$ \\
T118R & Nearshore off Kii Peninsula & 22 May 2017 & 138.0 & 187.6 & 44 & $9(4)^{*}$ \\
T131R & Nearshore off Kii Peninsula & 28 May 2017 & 118.0 & 178.2 & 42 & - \\
\hline
\end{tabular}



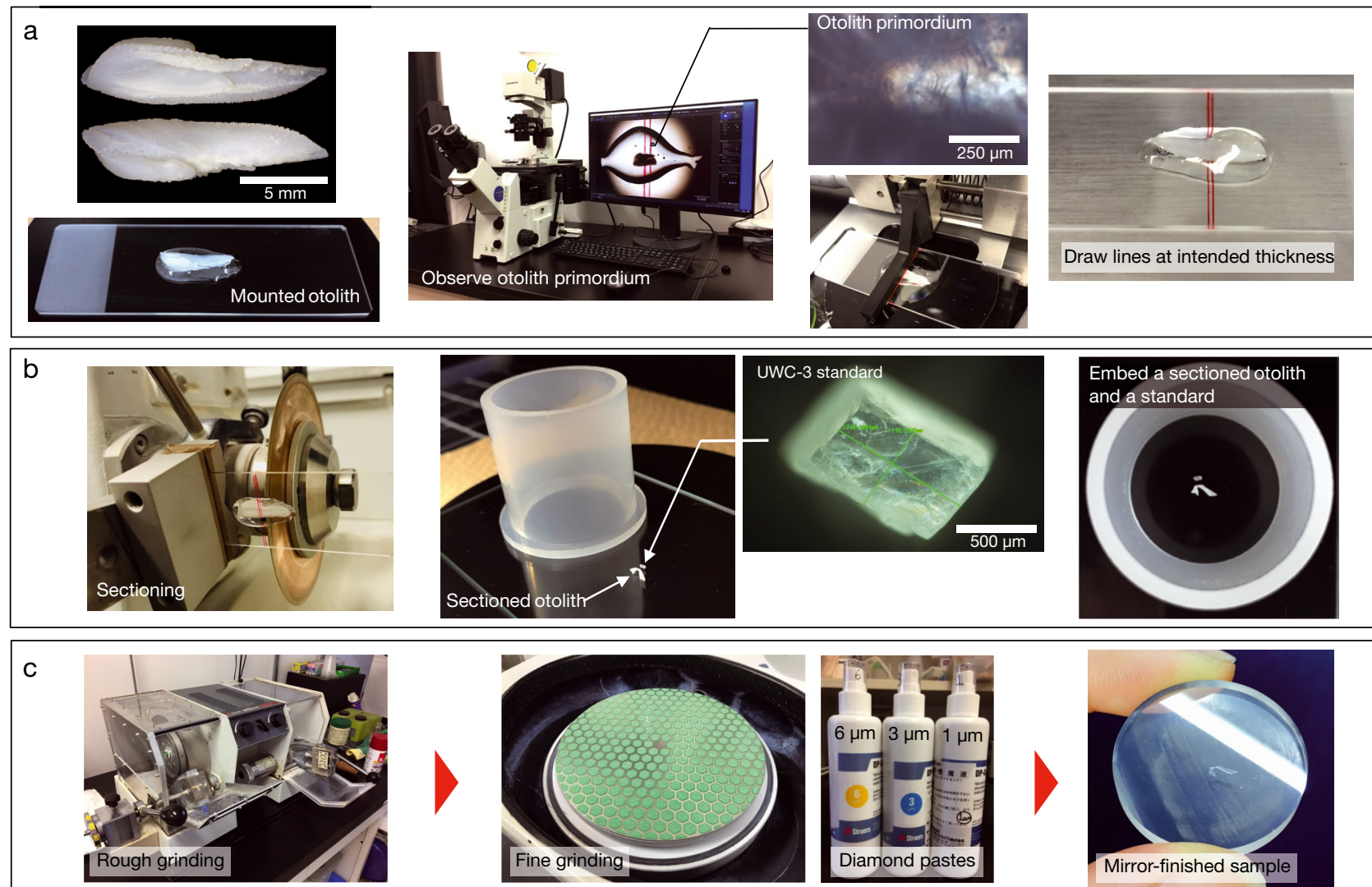

Fig. 2. Sample preparation protocol for SIMS $\delta^{18} \mathrm{O}$ analysis. (a) An otolith is mounted perpendicular to its longest axis with the sulcus side facing down on a glass slide with a crystal bond. The otolith primordium (core) is observed under an inverted microscope and lines are drawn on a glass slide on both sides of the primordium at 270 to $300 \mu \mathrm{m}$. (b) An otolith thin section is cut along the lines with a low-speed precision cutter. The thin-sectioned otolith is embedded along with a calcite UWC-3 standard in the center of a silicon mold with epoxy resin. (c) The epoxy disk is first ground with a grinding machine, and then successively polished with 6,3 , and $1 \mu \mathrm{m}$ diamond pastes to expose the primordium on a mirror-finished surface

comic pen nib holder with Tachikawa T-99 round pen nib), and a thin otolith section was cut out together with the slide glass along the drawn lines with an automatic low-speed precision cutter (IsoMet 5000, Buehler) equipped with a $0.3 \mathrm{~mm}$ thick diamond blade (IsoMet 15LC, Buehler). The sectioned otolith was then removed from the strip of glass by carefully rinsing it with acetone, and was allowed to air-dry in a laminar flow hood. The appropriate thickness of a sectioned otolith is subject to change depending on the species, and it is recommended that the thickness which provides the clearest view of the otolith growth increments should be determined for each species.

The sectioned otolith was fixed in the center of a $2.54 \mathrm{~cm}$ silicon mold and embedded in mounting resin (EpoxyCure 2 Resin, Buehler) along with a calcite standard, UWC-3 $\left(\delta^{18} \mathrm{O}=12.49 \%\right.$, Vienna Standard Mean Ocean Water [VSMOW], Kozdon et al. 2009), that was placed just above the otolith. It was then kept at room temperature for $24 \mathrm{~h}$ to cure the resin. The resulting epoxy disk containing the otolith thin section and standard material was ground with a grinding machine equipped with 70 and $13 \mu \mathrm{m}$ diamond cup wheels (Discoplan-TS, Struers) until the distance from the otolith surface to the core was 15 to $20 \mu \mathrm{m}$. It was then successively polished using 6, 3, and $1 \mu \mathrm{m}$ diamond pastes on a fine grinding disc (MD-Largo, Struers) to expose the core on a flat mirror-finished surface. Before analysis, the samples were cleaned in an ultrasonic cleaner and dried in a vacuum oven at $40^{\circ} \mathrm{C}$ for $2 \mathrm{~h}$. They were then sputtercoated with approximately $60 \mathrm{~nm}$ gold. This protocol reduces sample preparation time by eliminating the need to embed otoliths in epoxy resin twice (once for sectioning in the transverse or sagittal plane and once for embedding with standard materials and polishing). It also provides flexibility in deciding desired section thickness and minimizes the portion of the sample that needs to be polished. 


\subsection{SIMS $\delta^{18} \mathrm{O}$ analysis}

Otolith oxygen isotope ratios were measured in situ using a CAMECA IMS 1280-HR large radius, multicollector ion microprobe (SIMS) at the Kochi Institute for Core Sample Research, JAMSTEC. Five otolith thin sections were prepared for SIMS $\delta^{18} \mathrm{O}_{\text {otolith }}$ analyses using the sample preparation protocol developed in the present study (Fig. 2). The $\delta^{18} \mathrm{O}_{\text {otolith }}$ values were measured from otolith core to edge along the growth axis for each otolith sample (Fig. 3a).

The SIMS analytical conditions that were used for $\delta^{18} \mathrm{O}_{\text {otolith }}$ measurements in this study have been described in detail by Kita et al. (2009). The sample surface was sputtered by a $20 \mathrm{kV}$ accelerated ${ }^{133} \mathrm{Cs}^{+}$ primary ion beam at 1.5 to $1.8 \mathrm{nA}$ focused to a diameter of 10 to $15 \mu \mathrm{m}$, resulting in a pit of approximately $1 \mu \mathrm{m}$ depth (Fig. 3b). The secondary ions $\left({ }^{16} \mathrm{O}^{-},{ }^{18} \mathrm{O}^{-}\right.$, and $\left.{ }^{16} \mathrm{OH}^{-}\right)$were accelerated at $10 \mathrm{kV}$ and detected simultaneously by 3 Faraday cup detectors. Since hydrogen is present in the SIMS chamber even under ultra-high vacuum conditions, measured ${ }^{16} \mathrm{OH}^{-} /{ }^{16} \mathrm{O}^{-}$ratios were background-corrected by subtracting the average ${ }^{16} \mathrm{OH}^{-} /{ }^{16} \mathrm{O}^{-}$ratio of the UWC-3 standard bracketing analyses (nominally anhydrous minerals) from the ${ }^{16} \mathrm{OH}^{-} /{ }^{16} \mathrm{O}^{-}$ratio of $\delta^{18} \mathrm{O}_{\text {otolith }}$ measurements. The background-corrected ${ }^{16} \mathrm{OH}^{-} /{ }^{16} \mathrm{O}^{-}$ ratios served as a proxy for the relative hydrogen content contained in otolith samples. Each analysis took approximately $3 \mathrm{~min}$, consisting of pre-sputtering $(10 \mathrm{~s})$, automatic centering of the secondary ion beam (90 s), and the isotopic measurements with 20 analytical cycles $(40 \mathrm{~s})$. The count rates for ${ }^{16} \mathrm{O}^{-}$and ${ }^{18} \mathrm{O}^{-}$were 1.7 to $2.5 \times 10^{9}$ and 3.5 to $5.1 \times 10^{6}$ counts per second (cps), respectively.

For accurate calibration of SIMS $\delta^{18} \mathrm{O}$ measurements in biogenic carbonate samples, a homogeneous biocarbonate standard with a matched-matrix is needed. The UWC-3 standard is a chemically and isotopically homogeneous calcite standard which has a similar chemical composition to otoliths (aragonite), and thus all $\delta^{18} \mathrm{O}_{\text {otolith }}$ measurements were normal-

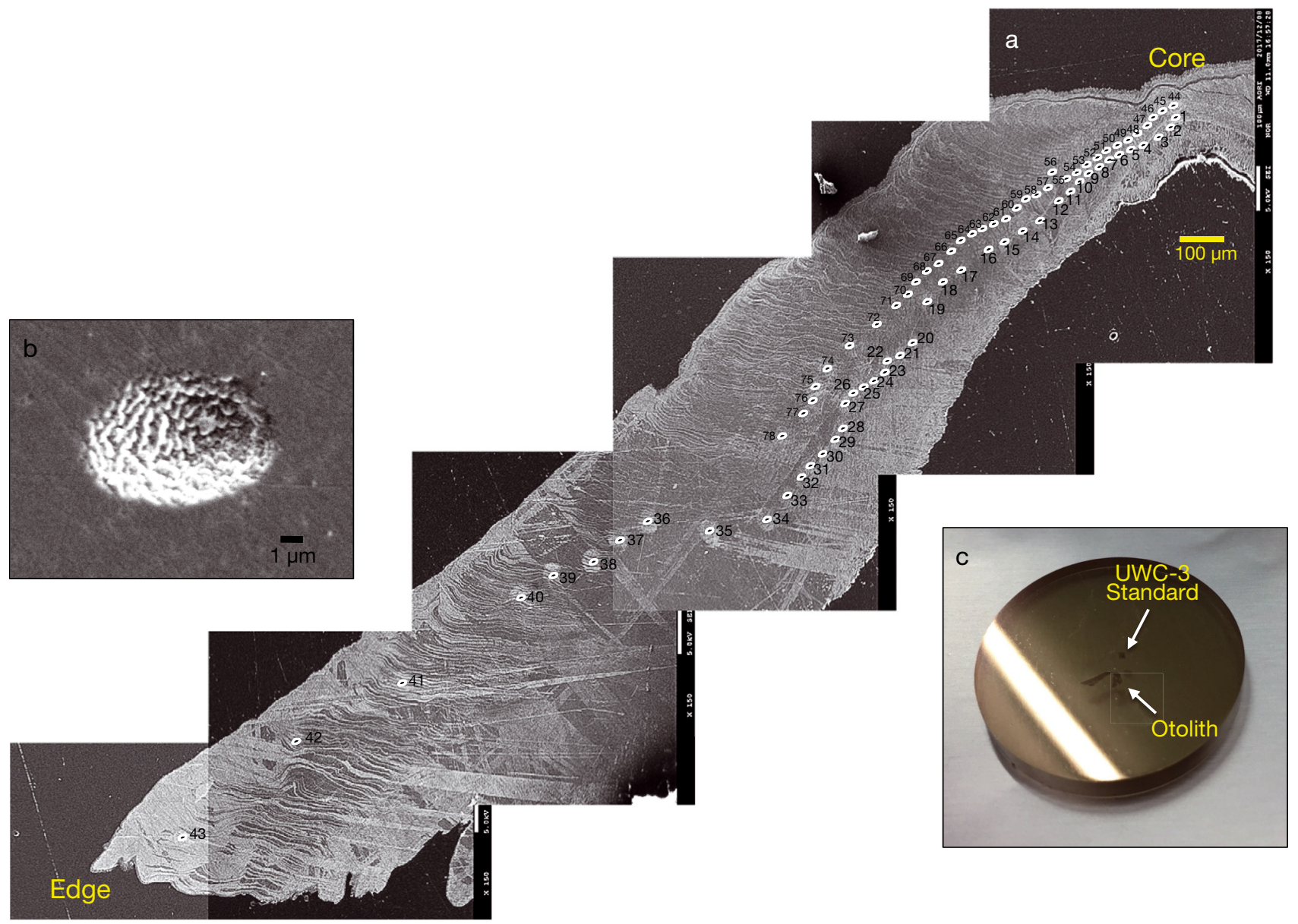

Fig. 3. (a) Cross-sectional electron probe micro analyzer (EPMA) image of bluefin tuna otolith with beam spot locations. (b) SIMS beam spot sputtered with a ${ }^{133} \mathrm{Cs}^{+}$primary ion beam focused to a diameter of 10 to $15 \mu \mathrm{m}$. (c) Otolith thin section from Pacific bluefin tuna Thunnus orientalis embedded in epoxy resin with a calcite UWC-3 standard. The sample surface was mirror-finished and coated with gold 
ized with this standard in our study (Kozdon et al. 2009). Every 10 to 15 unknown sample measurements were bracketed by 10 analyses of a UWC-3 calcite standard ( 5 analyses before and after each group of unknown samples) to calculate the spot-tospot precision of sample analyses and to correct for instrumental mass fractionation. The precision of sample analyses for all 5 otolith thin sections was \pm 0.3 to $\pm 0.6 \%$ ( 2 standard deviations).

After analysis, each spot was observed on scanning electron microscope (SEM) images taken with an electron probe micro analyzer (JXA-8230, JEOL) to check for any cracks and inclusions that might bias the resulting $\delta^{18} \mathrm{O}$ values (e.g. Weidel et al. 2007). No spots had such surface irregularities. In addition, the secondary ion yield $\left({ }^{16} \mathrm{O}^{-}, \mathrm{cps}_{\mathrm{nA}}{ }^{-1}\right)$ relative to the mean of the UWC-3 standard bracketing analyses were used to assess the quality of each spot measurement and check for any extreme outliers. Raw SIMS $\delta^{18} \mathrm{O}$ measurements are presented in Table S1 in the Supplement at www.int-res.com/articles/suppl/ m649p175_supp.xlsx.

For comparison purposes, all $\delta^{18} \mathrm{O}_{\text {otolith }}$ values were converted from VSMOW to Vienna Pee Dee Belemnite (VPDB) by using the latest published conversion equation $\left(\delta^{18} \mathrm{O}_{\text {VSMOW }}=1.03092 \times \delta^{18} \mathrm{O}_{\mathrm{VPDB}}+30.92\right.$, Brand et al. 2014, Kim et al. 2015).

\subsection{Microvolume $\delta^{18} \mathrm{O}$ analysis by CF-IRMS}

Microvolume CF-IRMS $\delta^{18} \mathrm{O}$ analysis was conducted to compare $\delta^{18} \mathrm{O}_{\text {otolith }}$ values measured by SIMS and CF-IRMS. Three otolith thin sections that had been analyzed by SIMS were used for microvolume
CF-IRMS $\delta^{18} \mathrm{O}$ analysis. $\delta^{18} \mathrm{O}$ analyses were performed with an IsoPrime100 isotope ratio mass spectrometer (Isoprime) equipped with a customized continuous-flow gas preparation system (MICAL3c) at the National Institute of Technology, Ibaraki College, Japan. This system can measure isotope ratios of calcium carbonate samples with a minimum sample mass of $0.2 \mu \mathrm{g}$ (about $1 / 100$ of the sample mass required for commercially available IRMS systems) with high precision and accuracy (Ishimura et al. 2004, 2008). By micromilling the otolith material deposited during the same growth period as that analyzed by SIMS, it is possible to compare average SIMS and CF-IRMS $\delta^{18} \mathrm{O}_{\text {otolith }}$ values.

A high precision micromilling system (Geomill326) was used for milling the specific regions of otolith samples. This system comprised a carbide bur fixed over an XYZ sample stage, a high-resolution camera, and a computerized image analyzer. An otolith image with marks indicating the target milling areas was imported into the system and milling paths were configured on the computer. The target milling areas were set in the otolith region where the measured SIMS $\delta^{18} \mathrm{O}_{\text {otolith }}$ values were stable, and they covered roughly 3 to 4 SIMS beam spots (Fig. 4). First, an unwanted area right next to the target milling path was milled and removed from the otolith to avoid cross-contamination. The removed otolith powders were also collected and used for analysis as supplementary samples to increase the dataset. For each otolith sample, 2 to 3 target paths were milled along the growth rings to obtain powder samples. The resulting milled paths were 15 to $80 \mu \mathrm{m}$ wide, 250 to $350 \mu \mathrm{m}$ long, and 60 to $90 \mu \mathrm{m}$ deep.

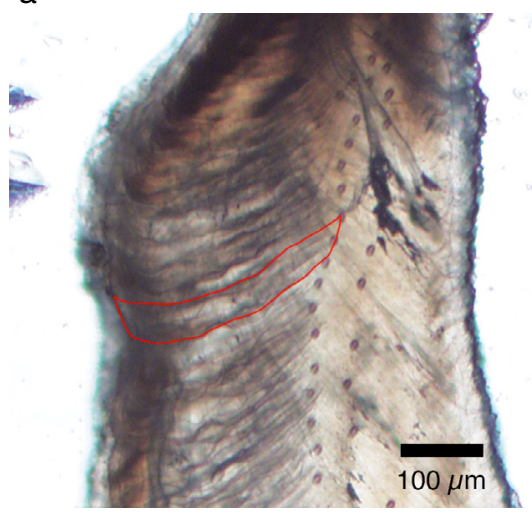

b

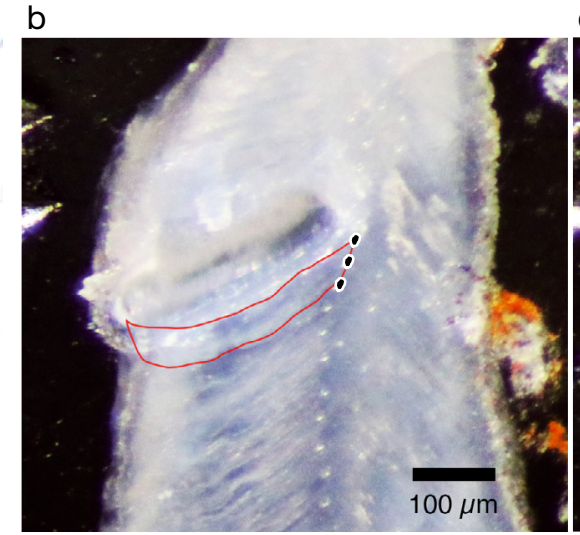

c

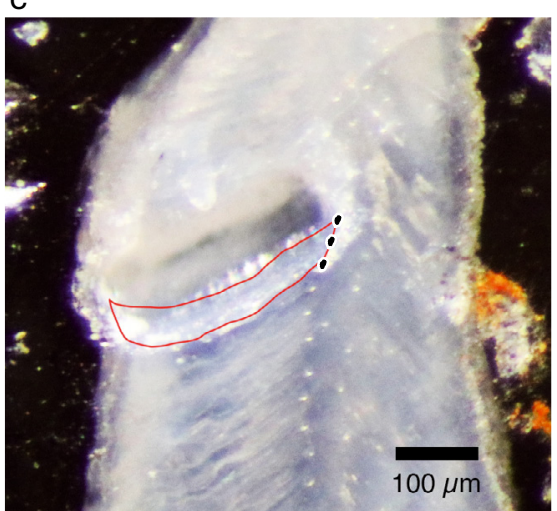

Fig. 4. Otolith thin section from Pacific bluefin tuna Thunnus orientalis (T64R) used for micromilling. (a) Before milling, (b) after milling unwanted areas to avoid cross-contamination, and (c) after milling the target milling path (the area inside the red line). (•) Beam spot locations where SIMS $\delta^{18} \mathrm{O}_{\text {otolith }}$ values are stable $(-3.01,-2.93,-3.04 \%$, respectively, from top to bottom [VPDB]). The images were taken under an optical microscope for (a), and a stereo microscope for (b) and (c) 
The life stages of the corresponding milled paths were estimated based on the distance from the otolith core and the location of the annual growth increments. Each path corresponded to either the juvenile (a few months old), immature (about 5 mo old to age 1+), or sub-adult stage (age 2 to 3 ). The non-parametric Kruskal-Wallis test was used to determine the statistical difference in resulting offset values between SIMS and CF-IRMS among different life stages.

The amount of powder produced from each path was 0.9 to $3.5 \mu \mathrm{g}$. The milled powder was carefully collected and placed on to a small piece of glass using a needle under a microscope, and then put into the bottom of a reaction tube. The aragonite powder was then reacted with $104 \%$ phosphoric acid at $25^{\circ} \mathrm{C}$, and the evolved $\mathrm{CO}_{2}$ was purified in a stainless steel vacuum line. After further purification using a heliumpurged purification line, the purified $\mathrm{CO}_{2}$ was introduced into the mass spectrometer. Samples that weighed more than $2.0 \mu \mathrm{g}$ were analyzed twice. The results are reported in standard $\delta$ notation (\%) relative to VPDB. We measured a laboratory standard $\mathrm{CO}_{2}$ gas for the determination of the analytical precision of pure $\mathrm{CO}_{2}$ gas $\left(\delta^{13} \mathrm{C}_{\mathrm{VPDB}}=-1.56 \%\right.$ and $\delta^{18} \mathrm{O}_{\mathrm{VPDB}}=-4.42 \%$, Nishida \& Ishimura 2017) 3 or more times every day. The analytical precision was better than $\pm 0.1 \%$ o ( $\pm 1 \mathrm{SD}$ ) for the entire analysis.

To compare the difference between SIMS and CFIRMS values, the average SIMS $\delta^{18} \mathrm{O}_{\text {otolith }}$ values were calculated by averaging the SIMS spot measurements adjacent to or within each milling path and then compared to the CF-IRMS $\delta^{18} \mathrm{O}_{\text {otolith }}$ value. A linear regression analysis was performed to determine the correlation between values measured by the 2 methods. In addition, the Wilcoxon signed rank test was applied to test the statistical difference between the average SIMS and CF-IRMS $\delta^{18} \mathrm{O}_{\text {otolith }}$ values, and the Tukey's test was used to detect outliers. All statistical analyses were performed using R software (version 3.3.2).

\subsection{Temperature reconstruction for larval stages of adult PBT}

Ambient water temperatures experienced during larval stages of adult PBT were estimated using SIMS $\delta^{18} \mathrm{O}_{\text {otolith }}$ values of otolith core regions. The daily growth increments were counted on the SEM images and the SIMS spot measurements that were made within 20 days post hatch (DPH) were used for the temperature estimation. For an accurate estimation of ambient water temperatures, a speciesspecific fractionation equation and $\delta^{18} \mathrm{O}_{\text {seawater }}$ are needed. To reconstruct ambient temperatures, we used the oxygen isotope fractionation equation for PBT larvae proposed by Kitagawa et al. (2013):

$\delta^{18} \mathrm{O}_{\text {otolith }(\mathrm{VPDB})}-\delta^{18} \mathrm{O}_{\text {water }(\mathrm{VPDB})}=5.193-0.270 \times T$ (1)

where $\delta^{18} \mathrm{O}_{\text {water }}$ is the $\delta^{18} \mathrm{O}$ value of ambient water, and $T$ is the water temperature in ${ }^{\circ} \mathrm{C}$. For $\delta^{18} \mathrm{O}_{\text {water }}$ in the equation, we applied the $\delta^{18} \mathrm{O}$ value of $+0.22 \%$ (VSMOW) which is the average $\delta^{18} \mathrm{O}_{\text {water }}$ of the main spawning ground around the Nansei Islands (24.04 to $26.09^{\circ} \mathrm{N}, 123.56$ to $131.00^{\circ} \mathrm{E}$ ) in May to June from 2008 to 2010 (Uozato 2011). The $\delta^{18} \mathrm{O}_{\text {water }}$ (VSMOW) value was corrected on the VPDB scale by subtracting $0.22 \%$ (Friedman \& O'Neil 1977), following the same protocol as Kitagawa et al. (2013). The mean temperatures were calculated for the samples that had multiple $\delta^{18} \mathrm{O}_{\text {otolith }}$ measurements made around the core regions. Although the focus was on the reconstruction of ambient water temperatures experienced during the larval period of the fish, the lifetime temperature history was estimated to evaluate how well $\delta^{18} \mathrm{O}_{\text {otolith }}$ records ambient water temperatures in the older stages of PBT.

\section{RESULTS}

\subsection{Comparison of SIMS and CF-IRMS $\delta^{18} \mathrm{O}_{\text {otolith }}$ measurements}

In total, 22 paths were milled by a micromilling system and the $\delta^{18} \mathrm{O}_{\text {otolith }}$ of collected powders from each milled path was measured by CF-IRMS (Table S2 in the Supplement). After carefully examining the accuracy of how well each milled path captured the same growth zone as the SIMS spots, 18 samples, including 9 main samples and 9 supplementary samples, were selected to assess the difference between SIMS and CF-IRMS $\delta^{18} \mathrm{O}_{\text {otolith }}$ values. The average values of multiple CF-IRMS measurements were used when the milling accuracy of a single milling path was low (see Table S3 in the Supplement for a complete list of data). The precision of $\delta^{18} \mathrm{O}_{\text {otolith }}$ values measured by CF-IRMS was better than that of SIMS.

The $\delta^{18} \mathrm{O}_{\text {otolith }}$ values measured by CF-IRMS were significantly higher than those measured by SIMS (Fig. 5a, Wilcoxon signed-rank test, $\mathrm{p}<0.001$ ) except for 2 measurements in which the CF-IRMS value was 0.12 and $0.47 \%$ lower than the average SIMS value, respectively. We considered the CF-IRMS $\delta^{18} \mathrm{O}_{\text {otolith }}$ measurement that was $0.47 \%$ lower than the average SIMS $\delta^{18} \mathrm{O}_{\text {otolith }}$ value to be an outlier, based on the Tukey's outlier detection method. This measurement was taken from a relatively large area of the otolith 

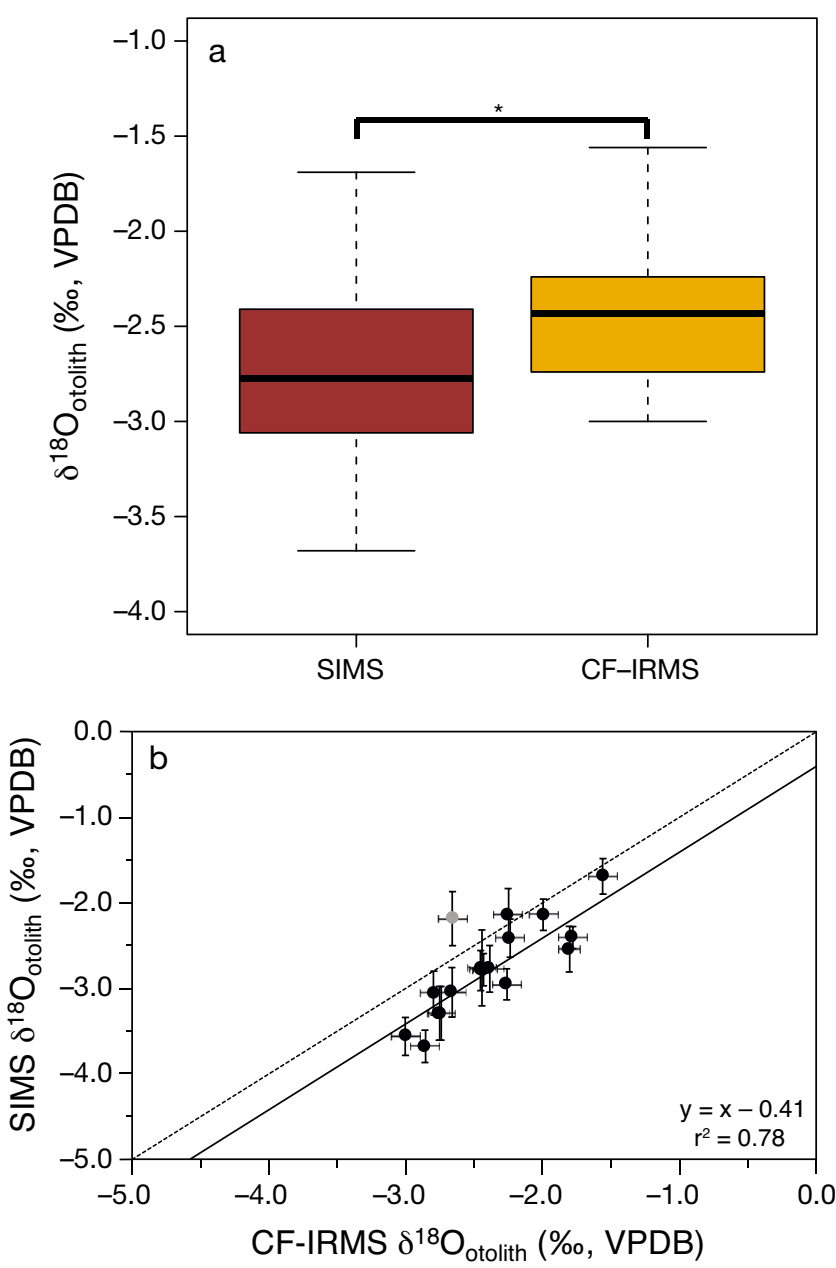

Fig. 5. Comparison of SIMS and CF-IRMS $\delta^{18} \mathrm{O}_{\text {otolith values }}$ (\%, VPDB). (a) CF-IRMS $\delta^{18} \mathrm{O}_{\text {otolith }}$ values were significantly higher than SIMS $\delta^{18} \mathrm{O}_{\text {otolith }}$ values. The bottom and top of the box represent the first (25th percentile) and third (75th percentile) quartiles of the data distribution, respectively. The thick horizontal line indicates the median, and the upper and lower whiskers represent the maximum and minimum values, respectively. ${ }^{*} \mathrm{p}<0.001$, Wilcoxon signedrank test. (b) SIMS $\delta^{18} \mathrm{O}_{\text {otolith }}$ values were $0.41 \%$ lower on

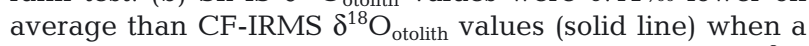
linear regression with a slope of 1 was fit to the data $\left(\mathrm{r}^{2}=\right.$ 0.78); (Dashed line) 1:1 slope. Horizontal and vertical error bars represent CF-IRMS analytical precision $( \pm 1 \mathrm{SD})$ and propagated error of the average SIMS measurements $( \pm 2 \mathrm{SD})$, respectively. Note that $1 \mathrm{CF}$-IRMS $\delta^{18} \mathrm{O}_{\text {otolith }}$ measurement (grey dot) that had a lower value than the average SIMS $\delta^{18} \mathrm{O}_{\text {otolith }}$ value was considered as an outlier based on Tukey's outlier detection method and thus excluded for the calculation of the average SIMS-CF-IRMS difference

deposited during the second to third years of life, where interannual variation in water temperature is expected. It is likely that this temperature variation was not well reflected in the average SIMS value since only 3 spot measurements were averaged over more than a half-year period. Therefore, this measurement was excluded for calculating a linear regression curve and the average SIMS-CF-IRMS difference.

There was a significant positive correlation between SIMS and CF-IRMS $\delta^{18} \mathrm{O}_{\text {otolith values }}\left(\mathrm{r}^{2}=0.79\right.$, $\mathrm{p}<0.001$ ) with a slope of 1.1408 and an intercept of 0.0704 . The slope is 1 within the $95 \%$ confidence interval (lower limit $=0.82$, upper limit $=1.46$ ) with a high correlation coefficient $\left(\mathrm{r}^{2}=0.78\right)$, and thus a linear regression with a slope of 1 was fitted to the data to calculate the $y$-intercept, which is the average difference (Fig. 5b). The average offset between SIMS

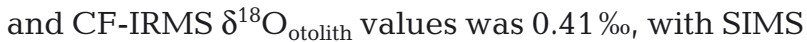
yielding lower values. The SIMS-CF-IRMS $\delta^{18} \mathrm{O}_{\text {otolith }}$ correction equation for PBT can be expressed as:

$$
\begin{aligned}
& \text { SIMS } \delta^{18} \mathrm{O}_{\text {otolith (VPDB) }}= \\
& \text { CF-IRMS } \delta^{18} \mathrm{O}_{\text {otolith (VPDB) }}-0.41
\end{aligned}
$$

No significant difference was observed between $\delta^{18} \mathrm{O}_{\text {otolith }}$ measurements at different life stages (KruskalWallis test, $\mathrm{p}=0.29$ ), and thus the consistent application of this offset correction equation to all SIMS measurements was considered appropriate.

\subsection{Seasonal variations in SIMS $\delta^{18} \mathrm{O}_{\text {otolith }}$ profiles}

In total, $259 \delta^{18} \mathrm{O}_{\text {otolith }}$ measurements were made for 5 PBT otoliths by SIMS (Table 1). The total number of spots measured per otolith was 42 to 78 (2 life-history transect lines were analyzed for T64R). The length of each transect ranged between 2.5 and $2.8 \mathrm{~mm}$ with a spot-to-spot distance ranging from 16 to $153 \mu \mathrm{m}$ around the core region, and 26 to $337 \mu \mathrm{m}$ toward the edge. The spatial resolution around the core region in one of the samples was more than 10 times higher compared to the conventional IRMS method previously used for PBT otoliths (Shiao et al. 2010). The temporal resolution of SIMS spots was 3 to $5 \mathrm{~d}$ near the core region and roughly several weeks to a month on the outer edge depending on the age of fish.

The offset-corrected SIMS $\delta^{18} \mathrm{O}_{\text {otolith }}$ values for 5 PBT samples are plotted in Fig. 6 (see left $y$-axis). High-resolution $\delta^{18} \mathrm{O}_{\text {otolith }}$ profiles of all otolith samples showed distinct seasonal variations with an increasing trend from the otolith core to about $1250 \mu \mathrm{m}$. The average $\delta^{18} \mathrm{O}_{\text {otolith }}$ values from the core to about $750 \mu \mathrm{m}$ ranged between -3.1 and $-2.5 \%$ (VPDB), and sharply increased toward the first annual increment (opaque zone), peaking at -1.3 to $-0.4 \%$. After the increase, the $\delta^{18} \mathrm{O}_{\text {otolith }}$ values decreased, showing a cyclical pattern toward the 

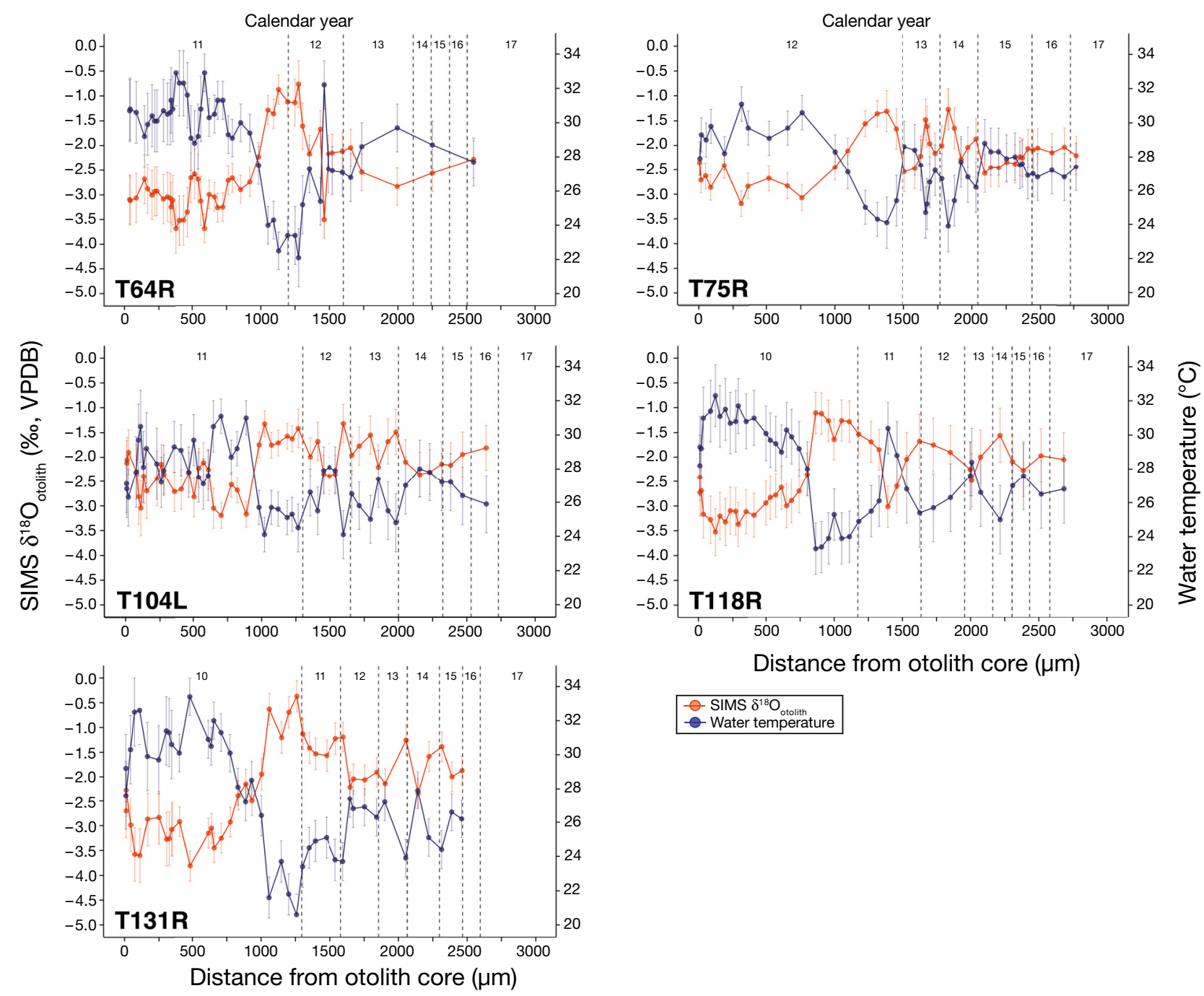

Distance from otolith core $(\mu \mathrm{m})$

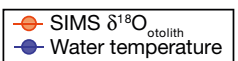

Fig. 6. Offset-corrected SIMS $\delta^{18} \mathrm{O}_{\text {otolith }}$ (orange plot, left $y$-axis) and reconstructed water temperature (dark blue plot, right $y$-axis) of 5 Pacific bluefin tuna Thunnus orientalis. Error bars represent the spot-to-spot precision of SIMS analyses and the estimated precision of the reconstructed water temperatures $( \pm 2 \mathrm{SD})$. Ambient water temperatures were estimated from the offset-adjusted SIMS $\delta^{18} \mathrm{O}_{\text {otolith }}$ values using an oxygen fractionation equation for Pacific bluefin larvae proposed by Kitagawa et al. (2013). Dashed vertical lines indicate the locations of annual increments (opaque zone), with numbers showing calendar years of otolith formation. Note $\delta^{18} \mathrm{O}_{\text {otolith }}$ at the most outer edge was not measured for T104L and T131R, and therefore dashed lines are shown beyond the plots

edge fluctuating mostly between -2.5 and $-1.5 \%$ (VPDB). The $\delta^{18} \mathrm{O}_{\text {otolith }}$ of the core regions corresponding to PBT larval stages (10 to $20 \mathrm{DPH})$ ranged between -3.1 and $-1.9 \%$ (VPDB).

The background-corrected ${ }^{16} \mathrm{OH}^{-} /{ }^{16} \mathrm{O}^{-}$ratios measured for the 5 otoliths ranged between 0.017 and 0.031 , and had a general inverse relationship with the SIMS $\delta^{18} \mathrm{O}_{\text {otolith }}$ values (there is no impact of individual differences on this relationship) (Fig. 7a). This indicates that the relative hydrogen content in the otolith increases with lower SIMS $\delta^{18} \mathrm{O}_{\text {otolith }}$ values. Overall, higher ${ }^{16} \mathrm{OH}^{-} /{ }^{16} \mathrm{O}^{-}$ratios resulted in larger SIMS-CF-
IRMS $\delta^{18} \mathrm{O}_{\text {otolith }}$ differences (Fig. $7 \mathrm{~b}$ ), which is consistent with the inverse trend seen in Fig. $7 \mathrm{a}$.

\subsection{Estimation of temperature experienced during larval period}

Core-to-edge water temperature profiles of all samples are shown in Fig. 6 (see right $y$-axis). The estimated temperatures experienced during the larval stages ranged between 26.7 and $30.7^{\circ} \mathrm{C}$ among the individuals (T64R: $30.7 \pm 1.3^{\circ} \mathrm{C}[\sim 20 \mathrm{DPH}], \mathrm{T} 75 \mathrm{R}$ : 

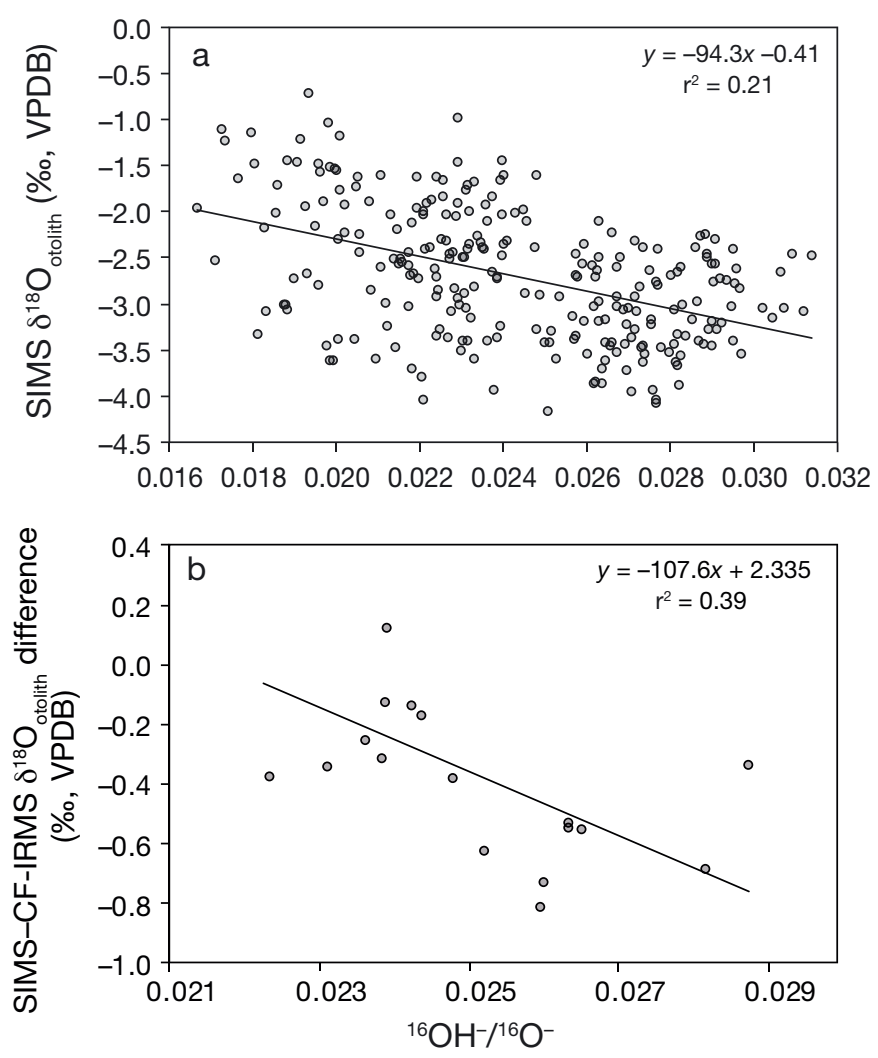

Fig. 7. Background-corrected ${ }^{16} \mathrm{OH}^{-} /{ }^{16} \mathrm{O}^{-}$ratios plotted against (a) SIMS $\delta^{18} \mathrm{O}_{\text {otolith }}$ values and (b) SIMS-CF-IRMS $\delta^{18} \mathrm{O}_{\text {otolith }}$ differences measured for otolith samples from 5 Pacific bluefin tuna Thunnus orientalis

$27.9 \pm 1.0^{\circ} \mathrm{C}[\sim 10 \mathrm{DPH}], \quad \mathrm{T} 104 \mathrm{~L}: 26.7 \pm 1.0^{\circ} \mathrm{C}$ [ 12 DPH], T118R: $28.9 \pm 0.9^{\circ} \mathrm{C}[\sim 12 \mathrm{DPH}], \mathrm{T} 131 \mathrm{R}:$ $\left.28.4 \pm 1.4^{\circ} \mathrm{C}[\sim 12 \mathrm{DPH}]\right)$. After Year 0, temperature ranged mostly between 24 and $30^{\circ} \mathrm{C}$, and never reached $35^{\circ} \mathrm{C}$.

\section{DISCUSSION}

An increasing number of experimental and modeling studies have shown significant impacts of projected climate change on the early growth and survival of various fish species (Kimura et al. 2007, Pankhurst \& Munday 2011, Moyano et al. 2017). Generally, fish larvae are more sensitive to temperature variations than juveniles and adults as they have narrower thermal tolerance ranges (Pörtner \& Peck 2010, Moyano et al. 2017), making them particularly vulnerable to climate change. However, the effects of ongoing climate change-driven ocean warming on the early life history of fish remain largely unexplored for many species, mostly due to difficulties in monitoring long-term responses to climatic stressors. Thus, the advancement of techniques that can quantitatively estimate past environments actually experienced by fish during key phases of the life cycle is essential to fill this knowledge gap. In this study, a high-resolution temperature reconstruction technique using SIMS $\delta^{18} \mathrm{O}_{\text {otolith }}$ analysis was developed and applied to PBT, a species of great economic importance, whose early larval growth and survival may be constrained by climate change.

The $0.41 \%$ offset observed between SIMS and CFIRMS $\delta^{18} \mathrm{O}_{\text {otolith }}$ values for PBT otoliths is most likely due to incomplete correction for 'matrix effects' by SIMS methods. Matrix effects refer to an instrumental mass fractionation caused by different chemical compositions and structures between given samples and standard materials, which shifts measured values (Eiler et al. 1997, Riciputi et al. 1998, Śliwiński et al. 2016, 2018, Wycech et al. 2018). Otoliths contain a small amount of organic proteins, namely otolith matrix protein-1 and Otolin-1 (Murayama et al. 2000, 2002). The presence of these proteins in the otolith would be responsible for a subtle change in instrumental mass fractionation, which results in lower SIMS $\delta^{18} \mathrm{O}_{\text {otolith }}$ values relative to those measured by CF-IRMS, and higher ${ }^{16} \mathrm{OH}^{-}$ion yields compared to that of the calcite standard. The general inverse relationship between ${ }^{16} \mathrm{OH}^{-} /{ }^{16} \mathrm{O}^{-}$ratios and SIMS $\delta^{18} \mathrm{O}_{\text {otolith }}$ values (Fig. 7a) may be the result of the incorporation of more proteins into the otolith matrix, which is thought to relate to fast growth in summer (or less proteins in winter due to slow growth). The water content $\left(\mathrm{OH}^{-}\right)$of the otoliths, if any, is also responsible for the lower $\delta^{18} \mathrm{O}_{\text {otolith }}$ values. These organic proteins and water content bias SIMS $\delta^{18} \mathrm{O}_{\text {otolith }}$ values because they are measured together with calcium carbonates, whereas they do not affect CF-IRMS $\delta^{18} \mathrm{O}_{\text {otolith }}$ values since these proteins do not react at $25^{\circ} \mathrm{C}$ with the phosphoric acid that is used in a digestion process to generate $\mathrm{CO}_{2}$ gas. Furthermore, the systematic difference in isotopic fractionations caused by sputtering different crystalline structures (the biogenic aragonite samples and calcite standard) may contribute to the observed offset (Linzmeier et al. 2016). Although matrix effects are likely the primary cause of the SIMS-CF-IRMS difference, other potential factors (e.g. milling and roasting effects) may influence the measurement results of SIMS and CF-IRMS. The effects of roasting and other factors have been discussed in detail by Wycech et al. (2018), who investigated the $\delta^{18} \mathrm{O}$ difference between SIMS and IRMS using foraminiferal shells. 
The offset of $0.41 \%$ found in this study is within the range of offset values previously reported for otoliths of other fish species and biocarbonate samples. Orland et al. (2015) reported that there is a consistent sample-dependent offset in $\delta^{18} \mathrm{O}$ of typically less than $1.0 \%$, but this can go up to $1.8 \%$ with different sample matrices including biocarbonates and speleothems. Matta et al. (2013) used roasting to remove organic materials and observed an offset of about $1 \%$ in SIMS $\delta^{18} \mathrm{O}$ values between roasted and unroasted otoliths of yellowfin sole Limanda aspera. Helser et al. (2018b) also observed a $0.5 \%$ offset between SIMS and CF-IRMS $\delta^{18} \mathrm{O}_{\text {otolith }}$ measurements in otoliths of Pacific cod Gadus macrocephalus. The temperature estimation without the correction of the $0.41 \%$ offset using SIMS $\delta^{18} \mathrm{O}_{\text {otolith }}$ values of PBT would cause a bias of $1.5^{\circ} \mathrm{C}$ in the estimates, resulting in some unrealistically high temperature estimates (i.e. $>34^{\circ} \mathrm{C}$ ). While the extent to which organic proteins and water content contribute to an overall offset is unknown, it is necessary to determine these offsets between SIMS versus IRMS when estimating ambient water temperatures from SIMS $\delta^{18} \mathrm{O}_{\text {otolith }}$ values for different species.

The SIMS analyses performed on 5 otolith samples from PBT revealed fine-scale $\delta^{18} \mathrm{O}_{\text {otolith }}$ profiles from the core to the edge with clear seasonal variations (Fig. 6). As water temperature and $\delta^{18} \mathrm{O}_{\text {otolith }}$ are negatively correlated (Devereux 1967, Thorrold et al. 1997, Høie et al. 2004), the initial increase in the $\delta^{18} \mathrm{O}_{\text {otolith }}$ values observed toward the first annual increment (opaque zone) for all otolith samples indicates that the PBT experienced a decreasing water temperature. Age 0 juveniles predominantly inhabit the surface mixed layer (Kitagawa et al. 2000), and they are known to migrate northward in summer along the coastal regions of Japan and southward for overwintering in the East China Sea and nearshore waters on the Pacific side of Japan (Itoh et al. 2003, Fujioka et al. 2018). The increase in the $\delta^{18} \mathrm{O}_{\text {otolith }}$ values thus reflects the actual water temperature change experienced by the individuals from autumn to winter. The increasing patterns of the $\delta^{18} \mathrm{O}_{\text {otolith }}$ in the first year of life observed in this study are consistent with the results previously reported by Shiao et al. (2010), with much greater temporal resolutions (d to wk) with high precision and accuracy achieved by SIMS techniques. The $\delta^{18} \mathrm{O}_{\text {otolith }}$ profiles after age 0 also showed similar seasonal fluctuations, but with much less variation. This narrow $\delta^{18} \mathrm{O}_{\text {otolith }}$ range observed after age 0 is likely due to the effect of the development of thermoregulatory ability by the PBT. For endothermic fish (warm-bodied) such as PBT and other tuna species, the $\delta^{18} \mathrm{O}_{\text {otolith }}$ of immature and adult stages do not merely reflect ambient (in situ) water temperatures but, rather, the elevated, internal body temperatures. Using counter current heat exchangers known as retia mirabilia (Dickson \& Graham 2004), PBT have the capacity to elevate the temperature of their viscera, red (slow-twitch, oxidative) myotomal muscle fibers, eyes, and brain (Linthicum \& Carey 1972, Carey \& Lawson 1973). When juvenile PBT reach about $20.0 \mathrm{~cm}$ in fork length at age 0 (about 2 mo after hatching) (Kubo et al. 2008), thermoregulatory ability begins to develop and they are able to maintain their body temperature $<1^{\circ} \mathrm{C}$ above that of the surrounding water (Furukawa et al. 2017). The thermoregulatory ability of PBT increases as the fish grow and develop. For example, water temperatures of the peritoneal cavity of adult fish (a $250 \mathrm{~kg}$ PBT) could be $10^{\circ} \mathrm{C}$ higher than ambient temperatures constructed from acoustic telemetry data (Kitagawa et al. 2006). Since temperatures $>35^{\circ} \mathrm{C}$ are lethal for $\mathrm{PBT}$, the observed upper temperature range $\left(30^{\circ} \mathrm{C}\right)$ in immature and adult stages is likely a result of physiological thermoregulation to avoid overheating. Understanding how thermoregulatory ability changes with body size and its physiological effects on $\delta^{18} \mathrm{O}_{\text {otolith }}$ will facilitate better interpretation of the temperature data obtained from this technique.

The estimated temperatures experienced during the larval stages ranged between 26.7 and $30.7^{\circ} \mathrm{C}$ among the individuals, with a mean temperature of $28.5 \pm 0.1^{\circ} \mathrm{C}( \pm 2 \mathrm{SD})$. Field surveys have collected PBT larvae in sea surface temperatures (SSTs) between 23.5 and $29.5^{\circ} \mathrm{C}$ in the 2 main spawning grounds (Yonemori 1989, Abe et al. 2014, Suzuki et al. 2014), with higher concentrations of larvae found around $27^{\circ} \mathrm{C}$. The estimated temperatures overlap with the range of temperatures observed for larval occurrence of PBT. As newly hatched PBT larvae tend to stay in warm waters within or near the spawning grounds for their optimal growth and survival, temperatures estimated from the core $\delta^{18} \mathrm{O}_{\text {otolith }}$ corresponding to the early larval period may also serve as a useful indicator of spawning temperatures or the location of spawning grounds. One of the specimens (T64R) appeared to have experienced relatively warm temperatures $\left(>30^{\circ} \mathrm{C}\right)$ associated with decreased growth rates and survival of larvae in the laboratory (Kimura et al. 2007). Although there is evidence that the eggs of PBT hatched as normal larvae at $31.5^{\circ} \mathrm{C}$ in rearing experiments (Miyashita et al. 2000), the higher temperature estimated for this specimen could be a result of the high-resolution sampling of SIMS which captured several warmer 
days. Despite the need to increase sample size to accurately judge whether the estimated temperatures are realistic, particularly for the specimens with higher temperatures, our results suggest that SIMS $\delta^{18} \mathrm{O}_{\text {otolith }}$ analysis coupled with a microvolume $\mathrm{CF}$ IRMS $\delta^{18} \mathrm{O}_{\text {otolith }}$ analysis and a species-specific temperature-dependent fractionation equation is an effective method for reconstructing ambient water temperatures experienced by fish and inferring their early life characteristics, which are difficult to obtain with the limited resolution of conventional methods.

\section{CONCLUSIONS}

We have developed a novel method to estimate ambient temperatures experienced during the larval stage of fish species using SIMS and microvolume CF-IRMS $\delta^{18} \mathrm{O}_{\text {otolith }}$ analyses. Microvolume $\delta^{18} \mathrm{O}_{\text {otolith }}$ analysis revealed that the SIMS $\delta^{18} \mathrm{O}_{\text {otolith }}$ values were $0.41 \%$ lower on average than CF-IRMS $\delta^{18} \mathrm{O}$ values. High-resolution SIMS $\delta^{18} \mathrm{O}_{\text {otolith }}$ analysis of PBT otoliths achieved greater spatial and temporal resolution with high precision and accuracy compared to the conventional IRMS methods. The $\delta^{18} \mathrm{O}_{\text {otolith }}$ profiles of all samples showed distinct seasonal variations, reflecting ambient water temperatures experienced by an individual fish. The developed protocol is useful especially for smaller otoliths with narrow growth increments. SIMS $\delta^{18} \mathrm{O}_{\text {otolith }}$ analysis coupled with micromilling and microvolume $\delta^{18} \mathrm{O}_{\text {otolith }}$ analysis allows microscale examinations of otoliths, and more detailed information on the thermal life history of fish can be obtained compared to conventional IRMS methods. This novel method is a powerful tool for the reconstruction of environmental histories of various fish species and has important implications for understanding how ocean warming is potentially affecting the early life history of fish.

Acknowledgements. This research was supported by Grantin-Aid for Scientific Research (JSPS KAKENHI Grant Numbers JP16K14968, 16H02944，18H04921，17K14413，17J$11417,17 K 18814)$ from the Japan Society for the Promotion of Science (JSPS). We are grateful to the Yamasa Wakiguchi Tuna Company for providing valuable fish samples. We thank Dr. Kenji Shimizu of the Kochi Institute, JAMSTEC for helpful discussion of the polishing protocol for biogenic carbonates.

\section{LITERATURE CITED}

Abe O, Masujima M, Suzuki N, Morimoto $H$ and others (2014) Current status of spawning grounds and periods of Pacific bluefin tuna. In: Japan Information Papers
(ISC/14/Plenary/Info/19). International Scientific Committee for Tuna and Tuna-Like Species in the North Pacific Ocean. Taipei, p 26-35. http://isc.fra.go.jp/pdf/ ISC14/ISC-14-Plenary-INFO-19_JPN_PBF_papers.pdf (accessed 6 Apr 2019)

Brand WA, Coplen TB, Vogl J, Rosner M, Prohaska T (2014) Assessment of international reference materials for isotope-ratio analysis (IUPAC technical report). Pure Appl Chem 86:425-467

Campana SE (1999) Chemistry and composition of fish otoliths: pathways, mechanisms and applications. Mar Ecol Prog Ser 188:263-297

Carey FG, Lawson KD (1973) Temperature regulation in free-swimming bluefin tuna. Comp Biochem Physiol A Comp Physiol 44:375-392

* Chen KS, Crone P, Hsu CC (2006) Reproductive biology of female Pacific bluefin tuna Thunnus orientalis from south-western North Pacific Ocean. Fish Sci 72:985-994

Devereux I (1967) Temperature measurements from oxygen isotope ratios of fish otoliths. Science 155:1684-1685

*Dickson KA, Graham JB (2004) Evolution and consequences of endothermy in fishes. Physiol Biochem Zool 77: 998-1018

Dufour E, Höök TO, Patterson WP, Rutherford ES (2008) High-resolution isotope analysis of young alewife Alosa pseudoharengus otoliths: assessment of temporal resolution and reconstruction of habitat occupancy and thermal history. J Fish Biol 73:2434-2451

Eiler JM, Graham C, Valley JW (1997) SIMS analysis of oxygen isotopes: matrix effects in complex minerals and glasses. Chem Geol 138:221-244

Friedman I, O'Neil JR (1977) Compilation of stable isotope fractionation factors of geochemical interest. In: Fleisher M, Chap KK (eds) Data of geochemistry, 6th edn. US Geol Surv Prof Pap 440:1-12

Fujioka K, Fukuda H, Furukawa S, Tei Y, Okamoto S, Ohshimo S (2018) Habitat use and movement patterns of small (age-0) juvenile Pacific bluefin tuna (Thunnus orientalis) relative to the Kuroshio. Fish Oceanogr 27: 185-198

Furukawa S, Fujioka K, Fukuda H, Suzuki N, Tei Y, Ohshimo S (2017) Archival tagging reveals swimming depth and ambient and peritoneal cavity temperature in age-0 Pacific bluefin tuna, Thunnus orientalis, off the southern coast of Japan. Environ Biol Fishes 100:35-48

Hanson NN, Wurster CM, EIMF, Todd CD (2010) Comparison of secondary ion mass spectrometry and micromilling/continuous flow isotope ratio mass spectrometry techniques used to acquire intra-otolith $\delta^{18} \mathrm{O}$ values of wild Atlantic salmon (Salmo salar). Rapid Commun Mass Spectrom 24:2491-2498

Helser T, Kastelle C, Crowell A, Ushikubo T, Orland IJ, Kozdon R, Valley JW (2018a) A 200-year archaeozoological record of Pacific cod (Gadus macrocephalus) life history as revealed through ion microprobe oxygen isotope ratios in otoliths. J Archaeol Sci 21:1236-1246

*Helser TE, Kastelle CR, McKay JL, Orland IJ, Kozdon R, Valley JW (2018b) Evaluation of micromilling/conventional isotope ratio mass spectrometry and secondary ion mass spectrometry of $\delta^{18} \mathrm{O}$ values in fish otoliths for sclerochronology. Rapid Commun Mass Spectrom 32: 1781-1790

Higuchi T, Ito S, Ishimura T, Kamimura Y and others (2019) Otolith oxygen isotope analysis and temperature history in early life stages of the chub mackerel Scomber japon- 
icus in the Kuroshio-Oyashio transition region. Deep Sea Res II 169-170:104660

Høie H, Otterlei E, Folkvord A (2004) Temperature-dependent fractionation of stable oxygen isotopes in otoliths of juvenile cod (Gadus morhua L.). ICES J Mar Sci 61:243-251

Imsland AK, Ólafsson K, Skírnisdóttir S, Gunnarsson S and others (2014) Life history of turbot in Icelandic waters: intra- and inter-population genetic diversity and otolith tracking of environmental temperatures. Fish Res 155: 185-193

IPCC (2007) Climate Change 2007: Synthesis Report. Contribution of Working Groups I, II and III to the Fourth Assessment Report of the Intergovernmental Panel on Climate Change. Core Writing Team, Pachauri RK, Reisinger A (eds) IPCC, Geneva

Ishimura T, Tsunogai U, Gamo T (2004) Stable carbon and oxygen isotopic determination of sub-microgram quantities of $\mathrm{CaCO}_{3}$ to analyze individual foraminiferal shells. Rapid Commun Mass Spectrom 18:2883-2888

Ishimura T, Tsunogai U, Nakagawa F (2008) Grain-scale heterogeneities in the stable carbon and oxygen isotopic compositions of the international standard calcite materials (NBS 19, NBS 18, IAEA-CO-1, and IAEA-CO-8). Rapid Commun Mass Spectrom 22:1925-1932

Itoh T, Tsuji S, Nitta A (2003) Migration patterns of young Pacific bluefin tuna (Thunnus orientalis) determined with archival tags. Fish Bull (Wash DC) 101:514-534

Jones JB, Campana SE (2009) Stable oxygen isotope reconstruction of ambient temperature during the collapse of a cod (Gadus morhua) fishery. Ecol Appl 19:1500-1514

Kai M (2007) Weight-length relationship of North Western Pacific bluefin tuna. In: Report of the Pacific Bluefin Tuna Working Group Workshop (ISC/07/PBFWG-3). International Scientific Committee for Tuna and Tuna-Like Species in the North Pacific Ocean, Shimizu, p 1-8. http://isc. fra.go.jp/pdf/PBF/ISC07_PBF_3/ISC_07_PBFWG3_07.pdf (accessed 6 Apr 2019)

Kalish JM (1991) Oxygen and carbon stable isotopes in the otoliths of wild and laboratory-reared Australian salmon (Arripis trutta). Mar Biol 110:37-47

Kim ST, Coplen TB, Horita J (2015) Normalization of stable isotope data for carbonate minerals: implementation of IUPAC guidelines. Geochim Cosmochim Acta 158: 276-289

Kimura S, Kiagawa T, Kato Y, Yamaoka N (2007) Fluctuation in spawning environment of bluefin tuna and Japanese eel associated with global warming and their ecological response. Kaiyo Mon 39:317-322

Kimura S, Kato Y, Kitagawa T, Yamaoka N (2010) Impacts of environmental variability and global warming scenario on Pacific bluefin tuna (Thunnus orientalis) spawning grounds and recruitment habitat. Prog Oceanogr 86: 39-44

Kita NT, Ushikubo T, Fu B, Valley JW (2009) High precision SIMS oxygen isotope analysis and the effect of sample topography. Chem Geol 264:43-57

Kitagawa T, Nakata H, Kimura S, Itoh T, Tsuji S, Nitta A (2000) Effect of ambient temperature on the vertical distribution and movement of Pacific bluefin tuna Thunnus thynnus orientalis. Mar Ecol Prog Ser 206:251-260

Kitagawa T, Kimura S, Nakata H, Yamada H (2006) Thermal adaptation of Pacific bluefin tuna Thunnus orientalis to temperate waters. Fish Sci 72:149-156

Kitagawa T, Ishimura T, Uozato R, Shirai K and others (2013) Otolith $\delta^{18} \mathrm{O}$ of Pacific bluefin tuna Thunnus orientalis as an indicator of ambient water temperature. Mar Ecol Prog Ser 481:199-209

*Kozdon R, Ushikubo T, Kita NT, Spicuzza M, Valley JW (2009) Intratest oxygen isotope variability in the planktonic foraminifer $N$. pachyderma: real vs. apparent vital effects by ion microprobe. Chem Geol 258:327-337

*Kubo T, Sakamoto W, Murata O, Kumai H (2008) Wholebody heat transfer coefficient and body temperature change of juvenile Pacific bluefin tuna Thunnus orientalis according to growth. Fish Sci 74:995-1004

Linthicum DS, Carey FG (1972) Regulation of brain and eye temperatures by the bluefin tuna. Comp Biochem Physiol A Comp Physiol 43:425-433

* Linzmeier BJ, Kozdon R, Peters SE, Valley JW (2016) Oxygen isotope variability within Nautilus shell growth bands. PLOS ONE 11:e0153890

* Matta ME, Orland IJ, Ushikubo T, Helser TE, Black BA, Valley JW (2013) Otolith oxygen isotopes measured by highprecision secondary ion mass spectrometry reflect life history of a yellowfin sole (Limanda aspera). Rapid Commun Mass Spectrom 27:691-699

Miyashita S, Tanaka Y, Sawada Y, Takii K, Mukai Y, Kumai $H$ (2000) Embryonic development and effects of water temperature on hatching of the bluefin tuna, Thunnus thynnus. Suisan Zoshoku 48:199-207

Moyano M, Candebat C, Ruhbaum Y, Álvarez-Fernández S, Claireaux G, Zambonino-Infante JL, Peck MA (2017) Effects of warming rate, acclimation temperature and ontogeny on the critical thermal maximum of temperate marine fish larvae. PLOS ONE 12:e0179928

Muhling BA, Lee SK, Lamkin JT, Liu Y (2011) Predicting the effects of climate change on bluefin tuna (Thunnus thynnus) spawning habitat in the Gulf of Mexico. ICES J Mar Sci 68:1051-1062

* Muhling BA, Liu Y, Lee SK, Lamkin JT, Roffer MA, MullerKarger F, Walter JF (2015) Potential impact of climate change on the Intra-Americas Sea: Part 2. Implications for Atlantic bluefin tuna and skipjack tuna adult and larval habitats. J Mar Syst 148:1-13

* Murayama E, Okuno A, Ohira T, Takagi Y, Nagasawa H (2000) Molecular cloning and expression of an otolith matrix protein cDNA from the rainbow trout, Oncorhynchus mykiss. Comp Biochem Physiol B Biochem Mol Biol 126:511-520

* Murayama E, Takagi Y, Ohira T, Davis JG, Greene MI, Nagasawa H (2002) Fish otolith contains a unique structural protein, otolin-1. Eur J Biochem 269:688-696

Nishida K, Ishimura T (2017) Grain-scale stable carbon and oxygen isotopic variations of the international reference calcite, IAEA-603. Rapid Commun Mass Spectrom 31: 1875-1880

* Ohshimo S, Tawa A, Ota T, Nishimoto S and others (2017) Horizontal distribution and habitat of Pacific bluefin tuna, Thunnus orientalis, larvae in the waters around Japan. Bull Mar Sci 93:769-787

Okochi Y, Abe O, Tanaka S, Ishihara Y, Shimizu A (2016) Reproductive biology of female Pacific bluefin tuna, Thunnus orientalis, in the Sea of Japan. Fish Res 174:30-39

Orland IJ, Kozdon R, Linzmeier B, Wycech J, Śliwiński M, Kitajima K, Kita N, Valley JW (2015) Enhancing the accuracy of carbonate $\delta^{18} \mathrm{O}$ and $\delta^{13} \mathrm{C}$ measurements by SIMS. Presentation PP52B-03. Am Geophys Union, Washington, DC https://ui.adsabs.harvard.edu/abs/ 2015AGUFMPP52B..03O/abstract (accessed 20 March 2019) 
Pankhurst NW, Munday PL (2011) Effects of climate change on fish reproduction and early life history stages. Aust J Mar Freshwater Res 62:1015-1026

Perry AL, Low PJ, Ellis JR, Reynolds JD (2005) Climate change and distribution shifts in marine fishes. Science 308:1912-1915

Pörtner HO, Peck MA (2010) Climate change effects on fishes and fisheries: towards a cause-and-effect understanding. J Fish Biol 77:1745-1779

Riciputi LR, Paterson BA, Ripperdan RL (1998) Measurement of light stable isotope ratios by SIMS: matrix effects for oxygen, carbon, and sulfur isotopes in minerals. Int J Mass Spectrom 178:81-112

Sakamoto T, Komatsu K, Shirai K, Higuchi T and others (2019) Combining microvolume isotope analysis and numerical simulation to reproduce fish migration history. Methods Ecol Evol 10:59-69

Shiao JC, Wang SW, Yokawa K, Ichinokawa M, Takeuchi Y, Chen YG, Shen CC (2010) Natal origin of Pacific bluefin tuna Thunnus orientalis inferred from otolith oxygen isotope composition. Mar Ecol Prog Ser 420:207-219

* Shiao JC, Itoh S, Yurimoto H, Iizuka Y, Liao YC (2014) Oxygen isotopic distribution along the otolith growth axis by secondary ion mass spectrometry: applications for studying ontogenetic change in the depth inhabited by deepsea fishes. Deep Sea Res I 84:50-58

* Shirai K, Otake T, Amano Y, Kuroki M and others (2018) Temperature and depth distribution of Japanese eel eggs estimated using otolith oxygen stable isotopes. Geochim Cosmochim Acta 236:373-383

Śliwiński MG, Kitajima K, Kozdon R, Spicuzza MJ, Fournelle JH, Denny A, Valley JW (2016) Secondary ion mass spectrometry bias on isotope ratios in dolomite-ankerite, Part I: $\delta^{18} \mathrm{O}$ matrix effects. Geostand Geoanal Res 40: $157-172$

Śliwiński MG, Kitajima K, Spicuzza MJ, Orland IJ, Ishida A, Fournelle JH, Valley JW (2018) SIMS bias on isotope ratios in Ca-Mg-Fe carbonates (Part III): $\delta^{18} \mathrm{O}$ and $\delta^{13} \mathrm{C}$ matrix effects along the magnesite-siderite solidsolution series. Geostand Geoanal Res 42:49-76

Suzuki N, Tanabe T, Nohara K (2014) Annual fluctuation in Pacific bluefin tuna (Thunnus orientalis) larval catch from 2007 to 2010 in waters surrounding the Ryukyu Archipelago, Japan. Bull Fish Res Agen 38:87-99

Tanaka S (2011) Skip spawning and spawning frequency of Pacific bluefin tuna around Japan. In: Report of the

Editorial responsibility: Myron Peck, Hamburg, Germany
Pacific Bluefin Tuna Working Group Workshop (ISC/11/ PBFWG). International Scientific Committee for Tuna and Tuna-Like Species in the North Pacific Ocean, Shimizu, p 14-15. http://isc.fra.go.jp/pdf/ISC11/Annex_5_ISC11_ PBFWG-1_FINAL.pdf (accessed 5 Apr 2019)

Thorrold SR, Campana SE, Jones CM, Swart PK (1997) Factors determining $\delta^{13} \mathrm{C}$ and $\delta^{18} \mathrm{O}$ fractionation in aragonitic otoliths of marine fish. Geochim Cosmochim Acta 61:2909-2919

Uozato R (2011) Validity of $\delta^{18} \mathrm{O}$ in otoliths of bluefin tuna Thunnus orientalis as an indicator for ambient environment. MSc dissertation, University of Tokyo, Kashiwa, Chiba (in Japanese)

Valley JW, Kita NT (2009) In situ oxygen isotope geochemistry by ion microprobe. In: Fayak M (ed) Secondary ion mass spectrometry in earth sciences. Mineralogical Association of Canada Short Course, 41, Mineralogical Association of Canada, Toronto, p 19-63

von Leesen G, Ninnemann US, Campana SE (2020) Stable oxygen isotope reconstruction of temperature exposure of the Icelandic cod (Gadus morhua) stock over the last 100 years. ICES J Mar Sci 77:942-952

Weidel BC, Ushikubo T, Carpenter SR, Kita NT and others (2007) Diary of a bluegill (Lepomis macrochirus): daily $\delta^{13} \mathrm{C}$ and $\delta^{18} \mathrm{O}$ records in otoliths by ion microprobe. Can J Fish Aquat Sci 64:1641-1645

*Willmes M, Lewis LS, Davis BE, Loiselle L and others (2019) Calibrating temperature reconstructions from fish otolith oxygen isotope analysis for California's critically endangered delta smelt. Rapid Commun Mass Spectrom 33: 1207-1220

*Wycech JB, Kelly DC, Kozdon R, Orland IJ, Spero HJ, Valley JW (2018) Comparison of $\delta^{18} \mathrm{O}$ analyses on individual planktic foraminifer (Orbulina universa) shells by SIMS and gas-source mass spectrometry. Chem Geol 483: $119-130$

Yonemori T (1989) To increase the stock level of the highly migrated pelagic fish. In: Agriculture, Forestry and Fisheries Research Council Secretariat (eds) Marine ranching. Koseisha-Koseikaku, Tokyo, p 8-59 (in Japanese)

Zazzo A, Smith GR, Patterson WP, Dufour E (2006) Life history reconstruction of modern and fossil sockeye salmon (Oncorhynchus nerka) by oxygen isotopic analysis of otoliths, vertebrae, and teeth: implication for paleoenvironmental reconstructions. Earth Planet Sci Lett 249: 200-215

Submitted: December 30, 2019; Accepted: July 28, 2020

Proofs received from author(s): September 7, 2020 